\title{
Eksistensi Kearifan Lokal dalam Pengaturan Pemilihan Kepala Desa Ditinjau dari Undrip (Studi Kasus Pemilihan Kepala Desa pada Masyarakat Adat Kedepatian Semerap Kabupaten Kerinci)
}

\author{
Dony Yusra Pebrianto*, Budi Ardianto, Taufan Dyusanda Putra \\ Fakultas Hukum Universitas Jambi \\ *correspondence email: dony_yusra@unja.ac.id
}

\begin{abstract}
Abstrak. Secara internasional The United Nations Declaration on the Rights of Indigenous Peoples (UNDRIP) menekankan penghormatan terhadap kearifan lokal masyarakat hukum adat. Pemilihan Kepala Desa merupakan salah satu konsep regulatif yang diatur di dalam Undang-Undang Nomor 6 Tahun 2014 tentang Desa. Pemilihan Kepala Desa dalam konsep undang-undang ini dilakukan secara serentak yang ditetapkan oleh Peraturan Daerah dan tata caranya diatur secara khusus melalui Peraturan Pemerintah sebagaimana diatur pada Pasal 31 Undang-Undang Nomor 6 Tahun 2014 tentang Desa. Namun ternyata dalam prakteknya khususnya pada masyarakat adat kedepatian semerap penyelenggaraan pemilihan kepala desa kerap berbenturan dengan pengaturan pemilihan kepala desa. Maka dalam hal ini rumusan masalah dalam penulisan ini yakni bagaimana pengaturan hak masyarakat adat dalam The United Nations Declaration on the Rights of Indigenous Peoples (UNDRIP) dan nilai dan konsep kearifan lokal apa saja yang berlaku dalam pemilihan kepala desa di 5 (Lima) Desa Kedepatian Semerap. Metode yang digunakan di dalam penulisan ini menggunakan metode yuridis empiris. Dan dalam hal ini disimpulkan UNDRIP mengatur perihal tentang hal-hal yang berkaitan dengan hak-hak individu serta hak kolektif yang sangat tertentu yang bersumber dari masyarakat adat. Dalam hal ini Negara berkewajiban melakukan perlindungan ataupun pemenuhan terhadap hak-hak masyarakat adat termasuk warisan budaya serta manifestasi budaya mereka termasuk sumber daya manusia dan genetika. Dan Pada masyarakat adat kedepatian semerap Kabupaten Kerinci terdapat suatu ketentuan adat dimana bakal calon kepala desa harus mendapat rekomendasi adat dan diangkat dari Depati dan Nenek Mamak. Ketentuan tersebut dipandang bertentangan dengan Paraturan Daerah setempat sehubungan dengan Pemilihan kepala desa. Maka mengingat ketentuan UNDRIP dan UUD 1945, maka Negara berkewajiban melindungi dan memelihara adat istiadat tersebut mengingat dampak positif yang timbul karenanya. Maka dalam hal ini ketentuan adat tersebut mestinya diatur di dalam Perda termasuk juga tentang pengakuan masyarakat adatnya. Di samping itu masyarakat perlu untuk membuka paradigma tentang HAM dalam pemilihan kepala desa di samping juga dalam paradigma pemberlakuan hukum adat perlu ada fleksibilitas dari Negara sepanjang tidak bertentangan dengan hukum nasional.
\end{abstract}

Kata Kunci: The United Nations Declaration on the Rights of Indigenous Peoples (UNDRIP), Pemilihan Kepala Desa, Desa, Hukum Adat, Kearifan Lokal

\begin{abstract}
Internationally The United Nations Declaration on the Rights of Indigenous Peoples (UNDRIP) emphasizes respect for the local wisdom of indigenous legal communities. The selection of village heads is one of the regulatory concepts stipulated in Law No. 6 of 2014 on Villages. The selection of village heads in the concept of this law is conducted simultaneously stipulated by local regulations and the procedures are specifically regulated through government regulations as stipulated in Article 31 of Law No. 6 of 2014 on Villages. But it turns out that in practice, especially in indigenous peoples, the deability of the village head election often clashes with the arrangement of the village head election. So in this case the formulation of the problem in this writing is how the arrangement of the rights of indigenous peoples in The United Nations Declaration on the Rights of Indigenous Peoples (UNDRIP) and the value and concept of local wisdom that applies in the selection of village heads in 5 (Five) Villages Semerap Kedepatian. The method used in this writing uses empirical juridical methods. And in this case it is concluded that UNDRIP regulates matters relating to individual rights as well as very specific collective rights sourced from indigenous peoples. In this case the State is obliged to protect or fulfill the rights of indigenous peoples including cultural heritage and their cultural manifestations including human resources and genetics. And in the indigenous people of kedepatian semerap Kerinci regency there is a customary provision where the prospective head of the village must get customary recommendations and be appointed from Depati and Nenek Mamak. The provision is considered contrary to the local Paraturan in relation to the election of the village head. So given the provisions of UNDRIP and the 1945 Constitution, the State is obliged to protect and maintain these customs given the positive impact that arises from it. So in this case the customary provisions should be regulated in the Regulation including also about the recognition of indigenous peoples. In addition, the community needs to open a paradigm on human rights in the selection of village heads in addition to the paradigm of the enforcement of customary law there needs to be flexibility from the State as long as it is not contrary to national law.
\end{abstract}

Keywords: The United Nations Declaration on the Rights of Indigenous Peoples (UNDRIP), Selection of Village Heads, Villages, Customary Law, Local Wisdom 
Dony Yusra Pebrianto, Budi Ardianto dan Taufan Dyusanda Putra, Eksistensi Kearifan Lokal dalam Pengaturan Pemilihan Kepala Desa Ditinjau dari Undrip (Studi Kasus Pemilihan Kepala Desa pada Masyarakat Adat Kedepatian Semerap Kabupaten Kerinci)

\section{PENDAHULUAN}

Merujuk kepada ketentuan Pasal 1 Ayat (43) Undang-Undang Nomor 23 Tahun 2014 tentang Pemerintahan Daerah yang mengatur:

Desa adalah desa dan desa adat atau yang disebut dengan nama lain, selanjutnya disebut Desa, adalah kesatuan masyarakat hukum yang memiliki batas wilayah yang berwenang untuk mengatur dan mengurus Urusan Pemerintahan, kepentingan masyarakat setempat berdasarkan prakarsa masyarakat, hak asal usul, dan/atau hak tradisional yang diakui dan dihormati dalam sistem pemerintahan Negara Kesatuan Republik Indonesia.

Konsepsi kekhasan masyarakat adat yang masih terafiliasi oleh kearifan lokal masyarakat adat diakui secara hukum bahkan oleh UUD 1945 sebagaimana diatur pada Pasal 18B Ayat (2) yang mengatur: "Negara mengakui dan menghormati kesatuan-kesatuan masyarakat hukum adat beserta hak-hak tradisionalnya sepanjang masih hidup dan sesuai dengan perkembangan masyarakat dan prinsip Negara Kesatuan Republik Indonesia, yang diatur dalam undang-undang". Bahkan kearifan lokal menjadi asas dalam penyelenggaraan Pemerintahan Desa yang mana merujuk kepada penjelasan Pasal 24 huruf i Undang-Undang Nomor 6 Tahun 2014 tentang Desa yang menjelaskan: "Yang dimaksud dengan "kearifan lokal" adalah asas yang menegaskan bahwa di dalam penetapan kebijakan harus memperhatikan kebutuhan dan kepentingan masyarakat Desa".

Merujuk kepada The United Nations Declaration on the Rights of Indigenous Peoples (UNDRIP) (selanjutnya disebut deklarasi masyarakat hukum adat) keberadaan keraifan lokal mendapat proteksi ekstra dalam kehidupan berbangsa dan bernegara. Termasuk kebijakan-kebijakan Negara tetap harus memperhatikan hak-hak masyarakat adat tersebut. Hal ini dikarenakan pandangan bahwa masyarakat adat adalah penyandang hak, dimana hak tersebut bukanlah merupakan pemberian siapapun termasuk Negara, namun hak masyarakat adat ini merupakan bawaan yang tidak dapat dipisahkan dari masyarakat adat itu sendiri. ${ }^{1}$

Istilah yang digunakan untuk menunjukkan masyarakat hukum adat semakin lazim dipergunakan, hal ini disebabkan karena lebih dekat dengan peristilahan yang digunakan dalam rumusan UUD 1945 yakni peristilahan kesatuan masyarakat hukum adat. Maka dalam hal ini terkesan bahwa peristilahan tersebut merupakan istilah yang dianggap paling sahih serta sesuai dengan perisitilahan yang digunakan di dalam konstitusi. ${ }^{2}$

Pemilihan Kepala Desa merupakan salah satu konsep regulatif yang diatur di dalam Undang-Undang Nomor 6 Tahun 2014 tentang Desa. Electoral process yang berlangsung di dalam pemilihan kepala desa adalah seluruh kegiatan yang terkait dengan langsung terhadap pemilihan kepala desa yang dalam hal ini merujuk dari suatu proses seleksi yang diselenggarakan pada tingkatan desa, pelaksanaan proses kampanye, pelaksanaan dalam hal pemilihan serta pelantikan terhadap calon yang mendapatkan perolehan suara terbanyak. ${ }^{3}$

Pemilihan Kepala Desa dalam konsep undang-undang ini dilakukan secara serentak yang ditetapkan oleh Peraturan Daerah dan tata caranya diatur secara khusus melalui Peraturan Pemerintah sebagaimana diatur pada Pasal 31 Undang-Undang Nomor 6 Tahun 2014 tentang Desa yang mengatur:

1) Pemilihan Kepala Desa dilaksanakan secara serentak di seluruh wilayah Kabupaten/Kota.

2) Pemerintahan Daerah Kabupaten/Kota menetapkan kebijakan pelaksanaan pemilihan Kepala Desa secara serentak sebagaimana dimaksud pada ayat (1) dengan Peraturan Daerah Kabupaten/Kota.

3) Ketentuan lebih lanjut mengenai tata cara pemilihan Kepala Desa serentak sebagaimana dimaksud pada ayat (1) dan ayat (2) diatur dengan atau berdasarkan Peraturan Pemerintah.

Kabupaten kerinci merupakan salah satu kabupaten di Provinsi Jambi yang masih menerapkan kearifan lokal dalam kehidupan sehari-hari, salah satunya adalah dalam hal pemilihan Kepala Desa. Dalam studi ini para Peneliti melokalisir lokasi penelitian dan menempatkan masyarakat kedepatian semerap sebagai objek penelitian.

Kedepatian Semerap merupakan suatu kerapatan ${ }^{4}$ yang dimana di dalamnya secara administratif terdapat lima desa yakni Desa Semerap, Desa Kotobaru Semerap, Desa Koto Tengah, Desa Pasar Semerap, dan Desa Koto Patah Semerap. Kedepatian Semerap masuk ke dalam wilayah administratif Kecamatan Keliling Danau Kabupaten Kerinci

${ }^{1}$ Lihat Noer Fauzi Rachman, Masyarakat Hukum Adat Adalah Bukan Penyandang Hak, Bukan Subjek Hukum, dan Bukan Pemilik Wilayah Adatnya, wacana JURNAL TRANSFORMASI SOSIAL, NO. 33|TAHUN XVI| 2014, hlm. 28.

${ }^{2}$ Lihat Yance Arizona, Masyarakat Adat dalam Kontestasi Pembaruan Hukum, Academia.edu, hlm. 1.

${ }^{3}$ Lihat Neneng Yani Yuningsih dan Valina Singka Subekti, Demokrasi dalam Pemilihan Kepala Desa? Studi Kasus Desa Dengan Tipologi Tradisional, Transisional, dan Modern di Provinsi Jawa Barat Tahun 2008-2013, Jurnal Politik, Vol. 1, No. 2, Februari 2016, hlm. 241

${ }^{4}$ Istilah kedepatian digunakan sejak dahulu oleh masyarakat Semerap sebagai suatu symbol kesatuan adat, sekalipun secara administrative hukum positif saat ini telah terbagi dalam 5 desa administrative. 
Provinsi Jambi. Kedepatian ini merupakan salah satu kekerabatan masyarakat adat yang masih mempertahankan dan memegang teguh hukum adat yang telah ada sejak zaman nenek moyang. Dalam catatan Darussami Ghazali ${ }^{5}$ Depati Nenek Mamak Kedepatian Semerap terdiri atas 3 Unsur, yakni Kelompok Depati yang terdiri atas Depati Mudo, Depati Payung, Depati Serago Putih, Depati Serago Hitam, Depati Simpan Negeri, Depati Nanggalo, Depati Lipan Negara, Depati Kecil. Kelompok Nenek Mamak terdiri atas Pemangku Adat, Rio Depsah, Rio Jayo, Rio Temenggung, Rio Sengajo, Rio Bentang, Rajo Betuah, Rajo Mudo, Rajo Pati, dan Menggung. Disamping itu dikenal pula istilah kelompok pegawai sara' yang terdiri atas: Kadhi Raja sebagai Ketua Alim Ulama, Imam Masjid Akbar Semerap, Khatib Masjid Akbar Semerap, dan Bilal Masjid Akbar Semerap.

Keberadaan istilah adat bersendi syara', syara' bersendi kitabullah dipegang erat oleh masyarakat kedepatian semerap. Dan dalam hal ini hubungan antara syara' dan adat dikenal dengan syara' mengato, adat memakai. Dalam catatan Darussami Ghazali ditulis:

Pepatah adat mengatakan sepucuk arah ke atas (satu pimpinan), Seakar arah ke bawah (satu rakyat yang bersatu), banyak tukang biduk menjadi balin (oleng), banyak takuk kayu tidak rebah.

Jadi kita hanya mengenal satu pimpinan yang dipatuhi. Tidak banyak pimpinan. Kalau ada perintah yang melanggar adat dan agama angkat ke rumah adat untuk dimusyawarahkan. ${ }^{6}$

Dalam hal pemilihan kepala desa masyarakat adat kedepatian semerap masih mempertahankan konsep adat yang memiliki kekhasan yang sebagaimana dituliskan dalam catatan di atas. Yang mana dalam hal ini musyawarah rumah gedang (rumah adat) menjadi kunci dalam pemilihan kepala desa di kedepatian semerap. Menurut Zaidan Latif: "Pemilihan Kepala Desa di Kedepatian Semerap tidak bisa bisa dilepaskan dari rumah gedang, khususnya dalam Pemilihan kepala desa agar terpilih calon yang jelas rekam jejak hidupnya"7.

Namun yang menjadi persoalan saat ini terjadi pro dan kontra sehubungan dengan penerapan hal tersebut. Di mana hal tersebut menjadi permasalahan di tengah masyarakat, mengingat ada yang pro dan kontra dengan permasalahan tersebut. Namun di satu sisi pengakuan terhadap kearifan lokal merupakan amanah hukum internasional dan bahkan konstitusi Negara mengakui hal tersebut, namun di satu sisi dalam aplikasinya khususnya dalam hal ini pemilihan kepala desa tidak mendapat pemngakuan konsep kearifan lokal tersebut. Hal ini pulalah yang dihadapi kedepatian semerap yang bahkan berujung kepada penundaan pemilihan kepala desa karena pro dan kontra tersebut.

Oleh karena itu para Penulis tertarik untuk meneliti tentang Sistem Pemilihan Kepala Desa yang menggunakan kearifan lokal masyarakat adat pada 5 (lima) Desa Kedepatian Semerap tersebut sebagai landasan pijak pemilihan kepala desa yang berkualitas tanpa mengenyampingkan hukum positif.

Bertolak kepada latar belakang masalah di atas, maka disusun perumusan masalah sebagai berikut:

1. Bagaimana pengaturan hak masyarakat adat dalam The United Nations Declaration on the Rights of Indigenous Peoples (UNDRIP)?

2. Nilai dan konsep kearifan lokal apa saja yang berlaku dalam pemilihan kepala desa di 5 (Lima) Desa Kedepatian Semerap?

\section{METODE}

Tipe penelitian yang Penulis gunakan adalah Tipe Penelitian yuridis normatif, penelitian yuridis normatif "...adalah suatu proses untuk menemukan aturan hukum, maupun doktrin-doktrin hukum guna menjawab isu hukum yang dihadapi". ${ }^{8}$

\section{HASIL DAN PEMBAHASAN}

\section{Pengaturan Hak Masyarakat Adat Dalam The United Nations Declaration On The Rights Of Indigenous Peoples} (UNDRIP)

Keberadaan masyarakat adat menjadi suatu bagian yang tidak terpisahkan dari Negara Indonesia, hal ini dikarenakan eksistensi serta nilai-nilai kearifan lokal yang dianut dan dipatuhi masyarakat adat telah jauh lama ada dan terlahir sebagai bagian dari sejarah panjang bangsa indonesia. Jambi.

${ }^{5}$ Alm. H. Darussami Ghazali adalah tokoh adat Kedepatian Semerap sekaligus mantan pengurus Lembaga Adat Melayu

${ }^{6}$ Darussami Ghazali, Sarak Mangato Adat Memakai, catatan Pribadi.

${ }^{7}$ Wawancara dengan Zaidan Latif, Tunggak Pumarang Desa Kedepatian Semerap pada Tanggal 18 Februari 2020. Tunggak pumarang adalah gelar adat yang diberikan kepada mantan Depati Nenek Mamak.

${ }^{8}$ Peter Mahmud Marzuki, Penelitian Hukum, Kencana Prenada Media Grup, Jakarta 2005, hlm 35. 
Hal ini dikarenakan keberadaan Negara kesatuan republik Indonesia dalam sejarahnya diawali dengan sejarah kekuasaan masyarakat adat yang terhimpun dalam kerajaan-kerajaan baik itu kerajaan besar maupun kerajaan kecil yang tersebar dari masa ke masa dari sabang sampai merauke. Di samping itu nilai-nilai hukum yang ada di Indonesia sedikit banyak tentunya terpengaruhi oleh nilai-nilai kearifan lokal yang hidup di tengah masyarakat hukum adat tersebut. Dalam definsinya jika dipandang dari substansinya dapat ditarik pemahaman bahwa hukum adat adalah suatu hukum yang dalam faktualnya senantiasa hidup serta berkembang pada kehidupan masyarakat, yang mana dalam hal ini senantiasa mengikuti perkembangan zaman, di samping itu memberikan suatu jaminan atas terciptanya ketertiban untuk masyarakat, serta mampu menjamin tercapainya keadilan. ${ }^{9}$

Dalam aspek unsurnya terdapat suatu komponen yang sangat utama dalam eksistensi masayarahat hukum adat yakni terdapatnya suatu hak yang dipunyai oleh masyarakat hukum adat. Dalam hal masyarakat hukum adat tersebut diakui dalam hal subjek hukum yang wajib mendapatkan perlindungan, maka dalam hal ini adalah suatu keharusan bagi Negara untuk melakukan pengakuan dan perlindungan terhadap hak-haknya. ${ }^{10}$

Di samping itu sebagai suatu konstruksi norma hukum internasional juga tentu mempengaruhi keberadaan hukum positif di Indonesia. Hukum internasional merupakan suatu hukum yang berlaku secara internasional dan keberlakuannya tersebut mengikat para pihak yang terikat dengan Perjanjian Internasional. Sehingga ada suatu konsep mengenai keberlakuan kaidah hukum internasional ke dalam hukum nasional. Dalam hal keberlakuan hukum internasional ke dalam hukum nasional Peter Malanczuk mengistilahkannya dengan istilah "Municipal Law". ${ }^{11}$

Dalam teorinya, dalam hal keberlakuan hukum internasional ke dalam hukum nasional lebih lanjut Peter Malanczuk menyatakan:

There are two basic theories, with a number of variations in the literature, on the relationship between international and domestic law. The first doctrine is called the dualist (or pluralist) view, and assumes that international law and municipal law are two separate legal systems which exist independently of each other. The central question then is whether one system is superior to the other. The second doctrine, called the monist view, has a unitary perception of the 'law' and understands both international and municipal law as forming part of one and the same legal order. The most radical version of the monist approach was formulated by Kelsen. In his view, the ultimate source of the validity of all law derived from a basic rule ('Grundnorm') of international law. Kelsen's theory led to the conclusion that all rules of international law were supreme over municipal law, that a municipal law inconsistent with international law was automatically null and void and that rules of international law were directly applicable in the domestic sphere of states. ${ }^{12}$

Berdasarkan pendapat di atas, dapat ditarik suatu pemahaman bahwa di dalam hubungan hukum internasional dengan hukum nasional, yakni dalam keberlakuan hukum internasional ke dalam hukum nasional terdapat dua doktrin yang disepakati, yakni:

a. Doktrin Dualisme atau yang dikenal juga dengan pandangan pluralis. Menurut doktrin ini Hukum Internasional dan Municipal Law merupakan dua sistem hukum yang terpisah. Yang mana antara satu dengan yang lainnya dapat berlaku secara bebas. Namun di sini timbul pertanyaan apakah salah satu sistem hukum tersebut memiliki kedudukan yang lebih tinggi jika dibandingkan dengan sistem hukum yang lainnya.

b. Doktrin Monisme, menurut doktrin ini antara Hukum Internasional dan hukum nasional harus disatukan menjadi suatu sistem hukum (meleburkan antara hukum internasional dan hukum nasional). Pandangan Monisme yang lebih radikal di sampaikan oleh Hans Kelsen. Menurutnya Hukum internasional harus ditegakkan sepenuhnya oleh Hukum nasional. Karena jika bertentangan maka ketentuan hukum nasional tersebut akan menjadi tidak sah karena bertentangan dengan ketentuan hukum internasional.

Dalam kaitannya dalam pergaulan internasional, setiap negara akan saling membutuhkan antara satu negara dengan negara lainnya dalam berbagai lapangan kehidupan. Dalam hal itu perlu keteraturan dalam penyelenggaraan hubungan antara satu negara dengan negara yang lainnya. Oleh karena itu perlu suatu pengaturan yang berbentuk suatu Perjanjian Internasional. Di samping itu dengan menjamurnya perjanjian internasional yang dalam hal ini

\footnotetext{
${ }^{9}$ Muazzin, Hak Masyarakat Adat (Indigenous Peoples) atas Sumber Daya Alam: Perspektif Hukum Internasional, Padjadjaran Jurnal Ilmu Hukum, Volume 1 - No 2 - Tahun 2014, Hlm. 329

${ }^{10}$ Ahmad Redi et.al, Konstitusionalitas Hak Masyarakat Hukum Adat atas Hak Ulayat Rumpon di Provinsi Lampung, Jurnal Konstitusi, Volume 14, Nomor 3, September 2017, Hlm. 483.

${ }^{11}$ Lihat Peter Malanczuk, Akehurst's Modern Introduction To International Law: Seventh Revised Edition, Routledge, New York, 1997, hlm. 63.

${ }^{12}$ Ibid.
} 
membentuk atau melahirkan hukum yang mendapat penerimaan oleh negara-negara di belahan dunia, dimana dalam keadaan tertentu suatu perjanjian internasional dalam hal ini mempersyaratkan wajib bagi negara-negara yang menjadi peserta untuk dapat mengimplementasikan hal-hal yang diatur perjanjian internasional tersebut ke dalam pengaturan hukum nasional, maka tentu negara-negara peserta perjanjian diharuskan dalam hal ini untu membuat suatu undangundang maupun melakukan dalam hal penyesuaian perundang-undangan nasional. ${ }^{13}$

Salah satu pengaturan hukum internasional adalah UNDRIP (The United Nations Declaration On The Rights Of Indigenous Peoples). UNDRIP merupakan salah satu deklarasi dalam tubuh PBB yang khusus mengatur tentang hakhak masyarakat adat. Deklarasi ini sendiri disahkan oleh majelis umum PBB pada tanggal 13 September 2007 dengan disetujui oleh mayoritas Negara yang mendukung saat itu yakni sebanyak 144 negara.

Penyusunan UNDRIP ini sendiri melalui waktu yang sangat panjang, yakni selama 22 tahun. Lahirnya deklarasi ini bertujuan untuk mendudukkan secara tegas hak individu maupun kelompok masyarakat adat dalam hal ini tentunya meliputi hak kemerdekaan terhadap segala aspek dalam kehidupan masyarakat adat tersebut. Kehadiran deklarasi ini juga bertujuan untuk menghapus segala bentuk diskriminasi terhadap masyarakat adat.

Struktur UNDRIP sendiri secara garis besar dapat dirumuskan sebagai berikut, Pasal 1 sampai dengan Pasal 40 UNDRIP pada intinya memuat pengaturan-pengaturan tentang hal-hal yang berkaitan dengan hak-hak yang menyakut individu maupun hak yang bersifat kolektif yang sangat tertentu yang berasal dari masyarakat adat. Selain itu dalam pasal-pasal tersebut juga diatur beberapa hal yang salah satunya adalah terkait dengan persoalan kewajiban dari negara dalam konteks melakukan perlindungan ataupun pemenuhan terhadap hak-hak sebagaimana dimaksud. Terlebih khusus lagi, merujuk Pasal 31 memuat pengaturan tentang hal yang berkaitan dengan hak bagi masyarakat adat untuk melakukan perlindungan terhadap warisan budaya serta manifestasi budaya mereka termasuk sumber daya manusia dan genetika.

Lebih lanjut, rumusan pada ketentuan Pasal 41 dan Pasal 42 UNDRIP merupakan rangkaian pengaturan terkait masyarakat adat khususnya mengenai peran serta Perserikatan Bangsa-Bangsa dalam fungsi dan kewenangannya. Selain itu merujuk kepada ketentuan Pasal 43 sampai dengan Pasal 45 UNDRIP yang mengatur sehubungan dengan keberlakuan hak-hak yang diatur di dalam UNDRIP di mana hak-hak yang diatur di dalam UNDRIP tersebut berlaku dengan tanpa adanya perbedaan pemberlakuan hak kepada laki-laki maupun perempuan dalam lingkup masyarakat adat, di samping itu pula ditekankan bahwa keberadaan hak-hak yang diatur di dalam UNDRIP merupakan suatu standar yang sifatnya minimum untuk kelangsungan hidup, martabat dan kesejahteraan masyarakat adat di dunia," dan sama sekali tidak membatasi hak yang lebih besar.

Dan menelisik lebih jauh kepada Pasal 46 UNDRIP yang mana di dalam pengaturannya terkait mengenai konsistensi Deklarasi terhadap tujuan yang bersifat lain yang mana dalam hal ini hal disepakati secara internasional, dan kerangka kerja untuk menafsirkan hak-hak yang dinyatakan di dalamnya.

\section{Nilai dan konsep kearifan lokal yang berlaku dalam pemilihan kepala desa di 5 (Lima) Desa Kedepatian Semerap}

Keberadaan masyarakat adat kedepatian semerap sudah sejak ratusan tahun ada dan hidup serta berkembang di tengah masyarakat kedepatian semerap. Secara historis memang merujuk kepada kawasan administrative pada mulanya hanya terdapat 1 Desa yakni Desa Semerap, namun pada perkembangannya Desa Semerap berkembang menjadi 3 (tiga) desa yakni Desa Koto Baru, Desa Semerap, dan Desa Patah. Hingga akhirnya sampai saat ini Kedepatian Semerap sudah dimekarkan menjadi 5 (lima) desa administrative yaitu Desa Semerap, Desa Koto Baru, Desa Koto Patah, Desa Pasar Semerap, dan Desa Koto Tengah. ${ }^{14}$

Pada prinsipnya proses penyelenggaraan pemerintahan desa di kedepatian semerap tidak terdapat kendala dan permasalahan yang signifikan kecuali di dalam hal pemilihan kepala desa itu sendiri, mengingat masyarakat kedepatian semerap memang mampu mengakulturasikan keberadaan adat dan peraturan yang berlaku di Negara. Hal ini jelas dikarenakan keberadaan nilai-nilai adat memang pada dasarnya tidak ada yang bertentangan dengan peraturan perundang-undangan yang berlaku. Maka dalam hal ini sekecil apapun penyelenggaraan pemerintahan desa sejauh ini senantiasa sejalan dengan penyelenggaraan nilai-nilai adat yang hidup dan berkembang di tengah masyarakat. ${ }^{15}$

Pemilihan kepala desa merupakan salah satu bagian penting dari proses demokrasi di Republik Indonesia yang diselenggarakan berjenjang mulai dari Presiden dan Wakil Presiden, Gubernur dan Wakil Gubernur, Bupati dan Wakil Bupati serta Walikota dan Wakil Walikota. Hal ini sebagai bentuk perwujudan dari konsepsi Negara demokrasi di Indonesia. Merujuk kepada ketentuan Pasal 1 Angka (1) Undang-Undang Nomor 6 Tahun 2014 tentang Desa

${ }^{13}$ Abdul Muthalib Tahar, Pengaruh Hukum Internasional Terhadap Pembentukan Hukum Nasional, Jurnal Selat, Mei Vol. 2 No. 2 Edisi 4, hlm. 230

${ }^{14}$ Wawancara dengan Mhd. Yusuf selaku Tokoh Masyarakat Kedepatian Semerap 2 Agustus 2020.

${ }^{15}$ Wawancara Padhil Tokoh Pemuda Kedepatian Semerap 1 Agustus 2020 
(selanjutnya disebut UU DESA) diatur bahwa desa terdiri atas desa serta dalam hal ini adalah desa adat. Desa sendiri dimaksudkan sebagai satu kesatuan dari masyarakat hukum yang dalam hal ini mempunyai batas-batas kewilayahan yang berkewenangan mengatur serta mengurus segala bentuk urusan kepemerintahan, di samping itu termasuk pula kepentingan-kepentingan masyarakat dengan berlandaskan keprakarsaan dari masyarakat. Dalam hal ini desa juga memiliki kewenangan mengatur terhadap hak atas asal usul, dan/atau hak-hak yang bersifat tradisionil yang berdasarkan konstitusi mendapatkan pengakuan dan penghormatan dalam sistem pemerintahan Negara Kesatuan Republik Indonesia. Dalam konsepsi hukum adat di Indonesia sangat dipengaruhi oleh mazhab sejarah yang dikemukakan oleh Von Savigny. Dalam perkembangannya pemikiran mengenai teori-teori hukum adat dikemukakan oleh pemikir-pemikir belanda lainnya. ${ }^{16}$

Sehubungan dengan pemilihan kepala desa sendiri diatur secara khusus melalui Peraturan Menteri Dalam Negeri Nomor 65 Tahun 2017 tentang Perubahan Atas Peraturan Menteri Dalam Negeri Nomor 112 Tahun 2014 Tentang Pemilihan Kepala Desa (selanjutnya disebut Permendagri Pilkades) dimana salah satu perubahan yang termasuk signifikan adalah penghapusan mengenai salah satu syarat menjadi calon kepala desa adalah terdaftar sebagai penduduk dan bertempat tinggal di Desa setempat paling kurang 1 (satu) tahun sebelum pendaftaran.

Dan secara khusus keberadaan pemilihan kepala desa di Kabupaten Kerinci diatur melalui Peraturan Daerah Nomor 8 Tahun 2018 tentang Perubahan Atas Peraturan Daerah Kabupaten Kerinci Nomor 12 Tahun 2015 tentang Pemberhentian dan Pemilihan Kepala Desa (selanjutnya disebut Perda Pilkades). Perda ini menjadi naungan penyelenggaraan Pemilihan Kepala Desa di Kabupaten Kerinci.

Sehubungan dengan nilai-nilai kearifan lokal yang diselenggarakan dalam Pemilihan Kepala Desa Di Kedepatian Semerap adalah diawali dengan syarat Bakal Calon Kepala Desa yang harus berasal dari Depati Ninik Mamak. dalam artian calon Kepala Desa harus menyandang gelar sebagai bagian dari Depati Ninik Mamak. Sehingga dalam hal ini tentu tertutup kemungkinan masyarakat umum untuk dapat dicalonkan menjadi Kepala Desa. Sekalipun pada dasarnya jika ditelaah dalam perspektif HAM tentu hal ini menimbulkan permasalahan mengingat bertentangan dengan prinsip equality before the law. Namun di sisi lain, tradisi masyarakat ini diyakini sampai saat ini oleh masyarakat mampu melahirkan kepala desa yang memiliki integritas dan moralitas yang baik mengingat sandaran pertimbangan syarat menjadi ninik mamak juga bersandar kepada hal tersebut. Maka pada dasarnya persoalannya ada pada hal ini dimana jika dikaji dalam perspektif HAM terjadi pertentangan terhadap tradisi masyarakat.

Dalam prosesnya Penjaringan proses seleksi bakal calon Kepala Desa di lingkungan lima desa dalam masyarakat Kedepatian Semerap dilakukan dalam tempo dimana Kepala Desa yang sedang menjabat akan memasuki akhir dari masa jabatannya. Adapun tahapan-tahapan yang dilalui dalam penjaringan dan seleksi bakal calon kepala desa diawali dengan musyawarah tertutup dimana dalam hal ini musyawarah tertutup ini hanya dihadiri oleh anggota Ninik Mamak yang sepuluh, yang hanya di hadiri oleh Nenek Mamak yang sepuluh yaitu terdiri atas Pemangku Adat, Rio Depsah, Rio Jayo, Rio Temenggung, Rio Sengajo, Rio Bentang, Rajo Betuah, Rajo Mudo, Rajo Pati, dan Menggung. Musyawarah tertutup ini dilakukan guna menentukan orang-orang yang secara adat maupun administrative memenuhi persyaratan untuk dapat dicalonkan sebagai calon kepala desa dalam hal ini adalah dalam lingkup lima desa kedepatian semerap. Bakal calon-bakal calon tersebut diambil dari kalangan Depati maupun Ninik Mamak mengingat dalam hukum adat kedepatian semerap Depati dan Ninik Mamak dibagi dalam jenis yang berbeda yang terhimpun dalam 4 jenis.

Nama-nama yang dimaksud dalam hal tersebut tidak mutlak diwajibkan berasal dari kalangan yang bersifat perwakilan dari pada kalangan Depati dan Nenek Mamak secara akumulatif, melainkan diperbolehkan berasal golongan Nenek Mamak saja ataupun Depati saja, sepanjang yang menjadi bakal calon tersebut berasal dari golongan Depati Ninik Mamak.

Untuk proses selanjutnya ninik mamak melakukan musyawarah guna menetukan orang-orang yang diajukan sebagai calon Kepala Desa yang selanjutnya hasil musyawarah Nenek Mamak tersebut akan dibawa ketahapan selanjutnya yaitu, melalui proses musyawarah yang dilakukan oleh Empat Jenis yang dilakukan di rumah gedang (sebutan rumah adat kedepatian semerap yakni di kediaman Depati Mudo. Dalam proses ini dihadiri oleh unsur-unsur empat jenis Depati dan Nenek Mamak, Kaum Tonggak Pemarang, Alim Ulama dan Cerdik Pandai. Dan kemudian di dalam inilah empat jenis menetapkan calon Kepala Desa yang akan mengikuti pemilihan kepala desa. Sehingga dalam hal ini calon-calon di luar yang disepakati oleh adat dan secara adat tidak diperkenankan secara adat untuk turut serta dalam pemilihan kepala desa di 5 (lima) desa kedepatian semerap. Hasil musyawarah tersebut kemudian diserahkan kepada Kepala Desa dimana pemilihan tersebut dilakukan yang dalam hal ini masih memegang jabatab tersebut atau

${ }^{16}$ Lihat Hayatul Ismi, Pengakuan Dan Perlindungan Hukum Hak Masyarakat Adat Atas Tanah Ulayat Dalam Upaya Pembaharuan Hukum Nasional, Jurnal Ilmu Hukum, Volume 3 No. 1, hlm. 2 
bisa jadi dalam hal ini kepada Pejabat Sementara atau Pelaksana Tugas Kepala Desa yang selanjtnya untuk diteruskan kepada Badan Permusyawaratan Desa (BPD) untuk selanjutnya dilakukan pemilihan Kepala Desa secara langsung. ${ }^{17}$

Namun hal tersebut kemudian menjadi permasalahan dimana pengaturan dan mekanisme pemilihan kepala desa yang khususnya diatur di dalam Peraturan Daerah Kabupaten Kerinci tidak lagi mengakomodir hal-hal yang diatur di dalam hukum adat. Hal ini tentu jika ditarik pemahaman dari aspek HAM adalah merupakan suatu bentuk pengakomodiran atas universalitas demokrasi itu sendiri. Dan tentu hal ini merupakan suatu ganjalan sendiri dalam proses pemilihan kepala desa yang masih mengakomodir dan mempertahankan mekanisme adat. Dalam hal kajian lebih lanjut sehubungan masyarakat adat dan HAM dimana salah satu bagainnya yaitu Hak atas Asasi Sosial dan Budaya, dimana masyarakat hukum adat berhak untuk berinovasi serta berkreasi. ${ }^{18}$

Dalam wawancara dengan Mat Rajab ${ }^{19}$ dari kalangan Cerdik Pandai Kedepatian Semerap, bahwa tentu pada umumnya keberadaan pembaharuan saat ini tentu tidak dapat dipungkiri. Kemajuan zaman dan teknologi tidak dapat dihindari yang sedikit demi sedikit masuk dan berarkulturasi dengan kehidupan masyarakat adat. Namun dalam hal ini nilai-nilai kearifan lokal tersebut perlu ditelaah tujuan dan manfaatnya. Salah satu tujuannya adalah tidak terjadi politik uang yang dikhawatirkan terjadi dalam Pilkades. Di samping itu untuk mendudukkan seseorang sebagai Depati Ninik Mamak melalui proses seleksi dan penelitian yang ketat. Sehingga setidaknya dapat dipastikan bahwa orangorang yang menempati posisi sebagai bagian dari Depati Ninik Mamak adalah orang-orang yang memiliki kapasitas, kualitas dan integritas. Sehingga jika dikaitkan dengan Pemilihan Kepala Desa dimana salah satu syaratnya adalah berasal dari Depati Ninik Mamak, maka tentu outputnya akan baik mengingat proses pencalonan melalui proses yang ketat.

Namun hal ini tentu bertentangan dengan Perda Pilkades terutama diatur pada Pasal 20 dimana dalam syarat menjadi Kepala Desa tidak lagi memuat mengenai syarat-syarat yang diberlakukan sesuai dengan adat-istiadat yang berlaku di desa setempat, mengerti dan memahami adat istiadat setempat serta tidak pernah terkena sanksi dan/atau hukum adat yang pada dasarnya diatur pada Perda Pilkades sebelumnya. Keberadaan pengaturan khusus di dalam Perda itu sendiri merupakan hal yang bersesuaian dengan syarat yang diatur pada Pasal 21 Permendagri tentang Pilkades dimana muatan lain boleh saja diatur di dalam Perda.

Merujuk kepada landasan konstitusional yakni pada Pasal 28 C Ayat (2) UUD 1945 yang pada prinsipnya mengatur sehubungan dengan perlindungan konstitusional terhadap hak individu untuk dapat memperjuangkan hakhak dalam hal kolektif untuk membangun masyarakat, bangsa, dan Negara. Lebih lanjut merujuk kepada Pasal 27 Ayat (1) UUD 1945 yang meletakkan persamaan hak warga Negara dalam hukum dan persamaan hak dalam bidang pemerintahan. Hal tersebut tentu menjadi suatu argument dimana pengekangan hak-hak individu menjadi suatu bentuk pelanggaran konstitusi dimana dalam hal ini konstitusi sangat menghormati dan melindungi hak-hak tersebut.

Dalam ketentuannya khususnya di dalam UU Desa memang pada hakikatnya desa dapat dibagi atas desa dan desa adat, yang dalam artinya desa adat yang masih memegang dan memelihara-nilai-nilai adat menjadi suatu bagian dari penamaan desa. Mahkamah Konstitusi di dalam pertimbangannya khususnya pada Putusan Nomor 128/PUUXIII/2015 menyatakan bahwa pada status desa sebagai suatu bagian yang tidak dapat dipisahkan dengan pemerintah daerah yang dalam hal ini melaksanakan perintah Peraturan Perundang-undangan sehingga secara resmi pemerintah desa merupakan perpanjangan tangan terbawah dari pemerintah daerah.

Namun dalam hal ini eksistensi desa adat sepanjang nilai adat tersebut masih hidup, dipatuhi dan berkembang di tengah masyarakat adat tentu harus mendapatkan ruang untuk bertahan. Apalagi melihat sejarah panjang bangsa Indonesia yang memang tidak dapat dipisahkan dari kebaradaan yang berkaitan dengan adat-istiadat serta hukumnya. Maka dalam hal ini tentu mengingat ruang desa adat tersebut diakomodir oleh Negara melalui peraturan perundangundangan tentu terbuka lebar peluang masyarakat adat mempertahankan nilai-nilai adatnya tersebut.

Selain itu pula jika merujuk lebih jauh terutama terhadap pengaturan UNDRIP dimana ketentuan ini khususnya di dalam Pasal 2 menjamin hak eksistensi masyarakat adat yang tentu termasuk pula di dalamnya adalah eksistensi hukum adatnya tersebut. Maka dalam hal ini disaat berbicara ada suatu hak di sana tentu ada suatu kewajiban yang melekat secara konstitusional pula dalam bingkai ketatanegaraan. Tentu dalam hal ini terdapat kewajiban Negara untuk menjamin hak-hak tersebut tanpa bisa mengabaikannya. Mengingat hak masyarakat adat tersebut merupakan

${ }^{17}$ Lihat Hainadri et.al, Peran Kaum Adat dalam Pelaksanaan Pemilihan Kepala Desa di Lima Desa Dalam Kedepatian Semerap Kecamatan Keliling Danau Kabupaten Kerinci Provinsi Jambi, Jurnal Al-Qisthu, Vol.15, No.2, December 2017, hlm. 44.

${ }^{18}$ Zidane Tumbel, Perlindungan Hukum Terhadap Hak-Hak Budaya Masyarakat Adat Dalam Perspektif Hukum Hak Asasi Manusia, Lex Et Societatis Vol. VIII/No. 1/Jan-Mar/2020, hlm. 5.

${ }^{19}$ Wawancara Mat Rajab Pada Tanggal 12 Agustus 2020 
bagian dari HAM, Maka dalam hal ini Negara memiliki 3 kewajiban yakni berkewajiban untuk melakukan perlindungan, menghormati serta memenuhinya. ${ }^{20}$

Hal ini sangatlah penting mengingat jati diri bangsa Indonesia yang memang lekat dengan adat istiadat yang terikat dengan sejarah panjang bangsa Indonesia. Maka dalam hal ini tentu Indonesia sangat berkepentingan dalam menjaga, merawat dan menjamin eksistensi hukum adat sepanjang berlaku, dipatuhi, dihormati serta dijalankan oleh masyarakat setempat sebagai bagian yang tidak dapat dipisahkan dari kerangka hukum nasional. Yang mana dalam hal ini jika dirujuk kepada Putusan Mahkamah Konstitusi Nomor 35/ PUU-X/2012 yang mana dalam limitasinya harus ada penetapan oleh Peraturan Daerah selaku masyarakat hukum adat. ${ }^{21}$ Pengaturan ini adalah suatu bentuk pengakuan masyarakat hukum adat sebagai subjek hukum untuk memperkuat eksistensi nilai hukum adat yang hidup di dalamnya.

Dalam hal ini tentu serta merta hukum adat tersebut tidak serta merta dapat berlaku, namun dalam hal ini diperlukan sandaran hukum yang kuat untuk memberlakukan ketentuan adat tersebut dengan tanpa sandaran hukum yang kuat dan tegas. Tentu dalam hal ini diperlukan political will dan pengaturan hukum. Maka dalam hal ini diperlukan itikad bersama untuk melakukan perlindungan hukum terhadap hukum adat yang dituangkan dalam peraturan khusus yakni Peraturan Daerah.

Namun di sisi lain, tentu dalam hal ini masyarakat perlu membuka diri terhadap perkembangan sosial dan tentunya perkembangan hukum. Paradigma masyarakat tentang HAM juga perlu untuk ditingkatkan, dengan hal tersebut sudah barang tentu masyarakat akan terbuka juga untuk menyesuaikan keberadaan hukum adat dengan hukum positif itu sendiri. Namun juga di sisi lain dalam perumusan peraturan perundang-undangan juga diperlukan penggalian terhadap nilai-nilai yang hidup di tengah masyarakat yang bernilai positif yang kemudian direduksi menjadi hukum nasional. Di samping itu juga mengingat Indonesia sebagai Negara yang tidak terlepas dari keberagaman adat istiadat sudah selayaknya juga Negara memberi fleksibilitas penerapan hukum adat sepanjang tidak bertentangan dengan hukum Negara.

\section{SIMPULAN}

1. UNDRIP mengatur perihal tentang hal-hal yang berkaitan dengan hak-hak individu serta hak kolektif yang sangat tertentu yang bersumber dari masyarakat adat. Dalam hal ini Negara berkewajiban melakukan perlindungan ataupun pemenuhan terhadap hak-hak masyarakat adat termasuk warisan budaya serta manifestasi budaya mereka termasuk sumber daya manusia dan genetika.

2. Pada masyarakat adat kedepatian semerap Kabupaten Kerinci terdapat suatu ketentuan adat dimana bakal calon kepala desa harus mendapat rekomendasi adat dan diangkat dari Depati dan Nenek Mamak. Ketentuan tersebut dipandang bertentangan dengan Paraturan Daerah setempat sehubungan dengan Pemilihan kepala desa. Maka mengingat ketentuan UNDRIP dan UUD 1945, maka Negara berkewajiban melindungi dan memelihara adat istiadat tersebut mengingat dampak positif yang timbul karenanya. Maka dalam hal ini ketentuan adat tersebut mestinya diatur di dalam Perda termasuk juga tentang pengakuan masyarakat adatnya. Di samping itu masyarakat perlu untuk membuka paradigma tentang HAM dalam pemilihan kepala desa di samping juga dalam paradigma pemberlakuan hukum adat perlu ada fleksibilitas dari Negara sepanjang tidak bertentangan dengan hukum nasional.

\section{DAFTAR PUSTAKA \\ Buku}

Peter Mahmud Marzuki, Penelitian Hukum, Kencana Prenada Media Grup, Jakarta 2005

Peter Malanczuk, Akehurst's Modern Introduction To International Law: Seventh Revised Edition, Routledge, New York, 1997

\section{Jurnal}

Abdul Muthalib Tahar, Pengaruh Hukum Internasional Terhadap Pembentukan Hukum Nasional, Jurnal Selat, Mei Vol. 2 No. 2 Edisi 4

Ahmad Redi et.al, Konstitusionalitas Hak Masyarakat Hukum Adat atas Hak Ulayat Rumpon di Provinsi Lampung, Jurnal Konstitusi, Volume 14, Nomor 3, September 2017.

\footnotetext{
${ }^{20}$ Yuliana Primawardani, Perlindungan Hak Masyarakat Adat Dalam Melakukan Aktivitas Ekonomi, Sosial Dan Budaya Di Provinsi Maluku, Jurnal HAM Vol. 8 No. 1, Juli 2017, hlm. 8.

${ }^{21}$ Lihat Mia Siscawati, Masyarakat Adat dan Perebutan Penguasaan Hutan, Wacana Jurnal Transformasi Sosial, Nomor 30, Tahun XV, 2014, hlm. 14.
} 
Dony Yusra Pebrianto, Budi Ardianto dan Taufan Dyusanda Putra, Eksistensi Kearifan Lokal dalam Pengaturan Pemilihan Kepala Desa Ditinjau dari Undrip (Studi Kasus Pemilihan Kepala Desa pada Masyarakat Adat Kedepatian Semerap Kabupaten Kerinci)

Hainadri et.al, Peran Kaum Adat dalam Pelaksanaan Pemilihan Kepala Desa di Lima Desa Dalam Kedepatian Semerap Kecamatan Keliling Danau Kabupaten Kerinci Provinsi Jambi, Jurnal Al-Qisthu, Vol.15, No.2, December 2017

Hayatul Ismi, Pengakuan Dan Perlindungan Hukum Hak Masyarakat Adat Atas Tanah Ulayat Dalam Upaya Pembaharuan Hukum Nasional, Jurnal Ilmu Hukum, Volume 3 No. 1

Mia Siscawati, Masyarakat Adat dan Perebutan Penguasaan Hutan, Wacana Jurnal Transformasi Sosial, Nomor 30, Tahun XV, 2014

Muazzin, Hak Masyarakat Adat (Indigenous Peoples) atas Sumber Daya Alam: Perspektif Hukum Internasional, Padjadjaran Jurnal Ilmu Hukum, Volume 1 - No 2 - Tahun 2014

Neneng Yani Yuningsih dan Valina Singka Subekti, Demokrasi dalam Pemilihan Kepala Desa? Studi Kasus Desa Dengan Tipologi Tradisional, Transisional, dan Modern di Provinsi Jawa Barat Tahun 2008-2013, Jurnal Politik, Vol. 1, No. 2, Februari 2016.

Noer Fauzi Rachman, Masyarakat Hukum Adat Adalah Bukan Penyandang Hak, Bukan Subjek Hukum, dan Bukan Pemilik Wilayah Adatnya, wacana Jurnal Transformasi Sosial, No. 33, Tahun XVI, 2014.

Yance Arizona, Masyarakat Adat dalam Kontestasi Pembaruan Hukum, Academia.edu.

Yuliana Primawardani, Perlindungan Hak Masyarakat Adat Dalam Melakukan Aktivitas Ekonomi, Sosial Dan Budaya Di Provinsi Maluku, Jurnal HAM Vol. 8 No. 1, Juli 2017

Zidane Tumbel, Perlindungan Hukum Terhadap Hak-Hak Budaya Masyarakat Adat Dalam Perspektif Hukum Hak Asasi Manusia, Lex Et Societatis Vol. VIII/No. 1/Jan-Mar/2020 